\section{Formation of Polyorganosiloxanes from Silicate Minerals}

SEVERAL attempts have been made ${ }^{1-5}$ to prepare trimethylsilyl derivatives of inorganic mineral silicates, that is, to convert $-\mathrm{Si}-\mathrm{O}-$ to $-\mathrm{Si}-\mathrm{O}-\mathrm{SiMe}_{3}$ in the hope that the preparation of these derivatives would both elucidate the structure of these silicates and provide a method for the preparation of new polyorganosiloxane materials of low cost. The original method proposed by Lentz ${ }^{1}$ has been improved by Götz and Masson ${ }^{2,6,7}$ and by Currell et al. $^{5}$ to give more reliable structural information on ortho and pyro silicates. The trimethylsilylation of chrysotile asbestos ${ }^{3,4}, \mathrm{Mg}_{3}\left(\mathrm{Si}_{2} \mathrm{O}_{5}\right)(\mathrm{OH})_{4}$, yielded a solid having a similar morphology to the original material with pendant trimethylsiloxy groups.

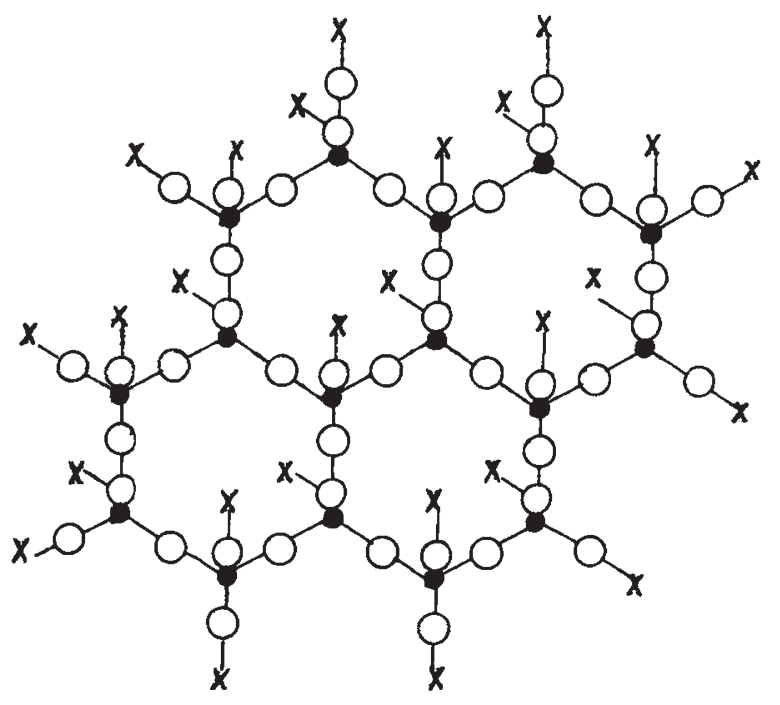

Fig. 1 Probable chief constituent of polymer derived from chlorite var. daphnite. Silicon; O, oxygen; $\times,\left(\mathrm{CH}_{3}\right)_{3} \mathrm{Si}-$.

We believe our work to be the first preparation of a polyorganosiloxane direct from an inorganic mineral silicate. Chlorite var. daphnite $(\mathrm{Fe}, \mathrm{Al}, \mathrm{Mg})_{12}\left[(\mathrm{Si}, \mathrm{Al})_{8} \mathrm{O}_{20}\right](\mathrm{OH})_{16}$ from Liskeard, Cornwall, was stirred vigorously for $72 \mathrm{~h}$ under reflux with isopropyl alcohol (100 ml.), hydrochloric acid $(d=1.18$, $50 \mathrm{ml}$.$) , and hexamethyldisiloxane (66.6 \mathrm{ml}$.). Evaporation of the hexamethyldisiloxane at $70^{\circ} \mathrm{C}$ for $15 \mathrm{~h}$, and at $170^{\circ} \mathrm{C}$ for $3 \mathrm{~h}$, yielded $3.2 \mathrm{~g}$ of an extremely high viscosity material (C, 29.9; H, 7.41; $\mathrm{Si}, 39.2 \%, M n=1,618)$. Infrared and NMR spectroscopic examinations made in conjunction with the elemental analysis are consistent with a polyorganosiloxane with trimethylsilyl side groups and, probably, a sheet structure. The material is a mixture, the chief constituent of which is probably that shown in Fig. 1. Heating the polymer for $30 \mathrm{~min}$ at $210^{\circ} \mathrm{C}$, pr. $6 \mathrm{~mm} \mathrm{Hg}$ gave a clear glassy material $(M n=2,248)$.

No other mineral studied yielded a fully trimethylsilylated derivative under the same reaction conditions. Bronzite ( $\mathrm{Mg}, \mathrm{Fe}) \mathrm{Si}_{2} \mathrm{O}_{6}$, hypersthene $(\mathrm{Mg}, \mathrm{Fe}) \mathrm{Si}_{2} \mathrm{O}_{6}$, prehnite $\mathrm{Ca}_{2} \mathrm{Al}$ $\left[\mathrm{Si}_{3} \mathrm{AlO}_{10}\right](\mathrm{OH})_{2}$, tremolite $\mathrm{Ca}_{2} \mathrm{Mg}_{5} \mathrm{Si}_{8} \mathrm{O}_{22}(\mathrm{OH})_{2}$, and diopside $(\mathrm{CaMg}) \mathrm{Si}_{2} \mathrm{O}_{6}$ showed little sign of reaction. Wollastonite $\mathrm{Ca}_{3} \mathrm{Si}_{3} \mathrm{O}_{9}$, anthophyllite $(\mathrm{Mg}, \mathrm{Fe})_{7} \mathrm{Si}_{8} \mathrm{O}_{22}(\mathrm{OH})_{2}$, hedenbergite $(\mathrm{Ca}, \mathrm{Fe}) \mathrm{Si}_{2} \mathrm{O}_{6}$, apophyllite $\mathrm{KFCa}_{4}\left(\mathrm{Si}_{8} \mathrm{O}_{20}\right) 8 \mathrm{H}_{2} \mathrm{O}$, and vermiculite $(\mathrm{Mg}, \mathrm{Fe}, \mathrm{Al})_{6}(\mathrm{Mg}, \mathrm{Ca})_{0.7}\left[(\mathrm{Si}, \mathrm{Al})_{8} \mathrm{O}_{20}\right](\mathrm{OH})_{4} 8 \mathrm{H}_{2} \mathrm{O}$ showed varying degrees of trimethylsilylation as determined by infrared spectroscopy, DTA and elemental analysis. These reaction products exhibited organophyllic properties, and had the same morphology as the original minerals. The analyses represent degrees of trimethylsilylation of one sixteenth of the available sites for hedenbergite, one fifth for wollastonite, two thirds for vermiculite and one tenth for apophyllite.

The results show that minerals which give rise to trimethylsilyl derivatives are those which react with hydrochloric acid. In conjunction with the work of Mase $^{8}$, Murata $^{9}$ and Petzold ${ }^{10}$ on the reactivity of silicate minerals with acids, some general rules may therefore be formulated. The reactivity of minerals towards acids depends both on the nature of the cations present and the "packing" of the silicate chains. The cations must be considered on the basis of ion size, electronegativity and electronic configuration. These factors are particularly important in structures where the silicate units are closely packed, such as pyroxenes, amphiboles, and mica-type structures. High iron (ferrous and ferric) and aluminium contents in the mineral favour acid attack, in hedenbergite, chlorite, and vermiculite, for example, whereas a predominance of calcium and magnesium tends to render the silicate inactive towards acids. The position of the ion within the structure $\left(M_{1}, M_{2}\right.$ and so on) is also important in this respect.

When the silicate chains or sheets are not closely packed-as in wollastonite and apophyllite- the cations are easily accessible to acids, and the principles outlined above can be overruled.

\section{B. R. CURRELl \\ H. G. Midgley \\ M. A. SEABORNE}

Department of Chemistry,

The Polytechnic of North London,

Holloway,

London N7 8DB

Received March 10, 1972.

1 Lentz, C. W., Inorg. Chem., 3, 574 (1964).

2 Götz, J., and Masson, C. R., J. Chem. Soc., A, 2683 (1970).

${ }^{3}$ Fripiat, J. J., and Mendelovici, E., Bull. Soc. Chim. France, 2, 483 (1968).

${ }^{4}$ Frazier, S. E., Bedford, J. A., Hower, J., and Kenney, M. E., Inorg. Chem., 6, 1693 (1967).

5 Currell, B. R., Midgley, H. G., and Seaborne, M. A., J. Chem. Soc., Dalton, 490 (1972).

6 Wu, F. F. H., Götz, J., Jamieson, W. D., and Masson, C. R., J. Chromatog., 48, 515 (1970).

7 Götz, J., and Masson, C. R., J. Chem. Soc., A, 686 (1971).

8 Mase, H., Bull. Chem. Soc. Japan, 34, 214 (1961).

9 Murata, K. J., Amer. Mineral., 28, 545 (1943).

10 Petzold, A., Wiss. Zeit. Hoch. Arch. Bauwesen, 13, 343 (1966).

\section{Untempered Ultra-high Strength Steels of High Fracture Toughness}

ULTRA-HIGH strength steels now in use were developed decades ago by trial and error methods, and they all have some undesirable characteristics, such as low fracture toughness at high levels of yield strength. So far there has been little effort to use the new concepts of alloying and micromechanics of fracture to improve existing alloys, or to find new ones with better combinations of properties. We are studying the factors that contribute to notch brittleness in high strength steels, and we have learned how to increase the fracture toughness of steels having yield strength in excess of 200,000 pound inch $^{-2}$ by as much as $70 \%$. We use treatments that differ significantly from the normal commercial practice for quenched and tempered low alloy steels, which involves heating to the lower end of the austenite temperature range (to minimize grain size), quenching fast enough to produce martensite, and tempering at a temperature that will optimize mechanical properties.

Fig. 1 shows the variation with austenizing temperature of 